\title{
Application of the Weathering Framework: Intersection of Racism, Stigma, and COVID-19 as a Stressful Life Event among African Americans
}

\author{
Fathima Wakeel ${ }^{1, *(1)}$ and Anuli Njoku ${ }^{2}$ (D) \\ 1 College of Health, Lehigh University, 1 W. Packer Ave., STEPS Building, Room 366, Bethlehem, PA 18015, USA \\ 2 Department of Public Health, College of Health and Human Services, Southern Connecticut State University, \\ 144 Farnham Avenue, New Haven, CT 06515, USA; njokua3@southernct.edu \\ * Correspondence: faw319@lehigh.edu; Tel.: +610-758-2625
}

check for updates

Citation: Wakeel, F.; Njoku, A

Application of the Weathering

Framework: Intersection of Racism, Stigma, and COVID-19 as a Stressful Life Event among African Americans. Healthcare 2021, 9, 145. https:// doi.org/10.3390/healthcare9020145

Academic Editor:

Jocelyn Turner-Musa

Received: 19 December 2020

Accepted: 27 January 2021

Published: 2 February 2021

Publisher's Note: MDPI stays neutral with regard to jurisdictional claims in published maps and institutional affiliations.

Copyright: (c) 2021 by the authors. Licensee MDPI, Basel, Switzerland. This article is an open access article distributed under the terms and conditions of the Creative Commons Attribution (CC BY) license (https:/ / creativecommons.org/licenses/by/ $4.0 /)$.

\begin{abstract}
The disproportionate impact of coronavirus disease 2019 (COVID-19) on African American communities necessitates an increased focus on the intersectional roles of racism, stigma, and other social determinants of health in influencing disease and mortality risk. The Weathering Framework is applied to demonstrate the dynamic interrelationships between these factors and to conceptualize COVID-19 as a stressful life event that will have profound health implications over the life course for African Americans. Recommendations for population health research, interventions and policies aimed at reducing COVID-19 incidence and mortality, and mitigation of the long-term impacts of the pandemic on communities of color are discussed.
\end{abstract}

Keywords: health disparities; COVID-19/coronavirus; stigma; race/ethnicity; social determinants of health; Blacks / African Americans; racism; systemic racism

\section{Introduction}

The "coronavirus disease 2019" (COVID-19), a pandemic of lower respiratory tract disease caused by severe acute respiratory syndrome coronavirus 2 (SARS-COV-2) infection and resulting in severe illness and potential death from pneumonia-like symptoms, has significantly beset communities across the world [1-3]. As of 16 December 2020, there are over 73.9 million cases of COVID-19 and over 1.6 million COVID-19-related deaths globally [4,5]. The United States (U.S.) has the most COVID-19 deaths, at over 311,000 people, along with over 17.1 million cases and over 10 million recovered patients $[5,6]$. Persons at higher risk for COVID-19 include adults of any age with certain underlying medical conditions such as cancer, chronic kidney disease, heart conditions, weakened immune system, obesity, smoking, type 2 diabetes mellitus, pregnancy, and sickle cell disease [7]. In addition, African Americans, compared with all other racial/ethnic groups, are more likely to contract COVID-19 and die of the disease [8-10]. Data from the Centers for Disease Control and Prevention (CDC) [11] show that compared to non-Hispanic Whites, deaths are 2.8 times higher among Black/African Americans, 2.6 times higher among American Indian or Alaska Native, non-Hispanic persons, 2.8 times higher among Hispanic/Latino persons, and 1.1 times higher among Asians.

While predisposition to underlying health conditions, such as hypertension, diabetes, high blood pressure, and asthma, play a role in COVID-19 racial disparities, a history of exposure to marginalization, discrimination, and racial trauma resulting from a "hierarchy of citizenship" [12], p.2 and subsequent unequal "citizenship in practice" [12], p.5; systemic barriers such as systematic racism within the healthcare system; likelihood of being uninsured; reduced access to affordable medical testing; and denied access to COVID-19 testing, diagnosis, and management also likely contribute to poor COVID-19 health outcomes among African American populations [12-14]. Therefore, the disproportionate impact 
of COVID-19 on African American communities necessitates an increased focus on the intersectional roles of racism, stigma, and other determinants of health in influencing disease and mortality risk. In this paper, we contribute to the literature by proposing an integrated Weathering Framework to demonstrate the dynamic interrelationships between these factors, and to conceptualize COVID-19 as a stressful life event that will have profound health implications over the life course for African Americans.

\section{Racism and Health}

Over the past few decades, researchers and practitioners have identified racism as a pervasive population health crisis and a root cause of disease in the U.S. and globally. Studies have extensively demonstrated the multifaceted relationships between racismspecifically cultural, interpersonal, and structural racism-and health outcomes among African Americans. At the broadest level, cultural racism, which entails the denigration of a minority group through derogatory and exclusionary stereotypes, imagery, media, and social norms, has been shown to impact health through four key pathways, including stereotype threat, internalized racism, interpersonal racism, and structural racism [15-17]. Stereotype threat, defined as "anxieties and expectations that can be activated in stigmatized groups when negative stereotypes about their group are made salient" [17], p. 111, has been associated with an impaired patient-physician relationship, engagement in unhealthy behaviors, reduced compliance with treatment recommendations, higher blood pressure, and weight gain among minority groups [18]. Further, internalized racism, which is when individuals in minority groups implicitly accept negative stereotypes about the group, has been linked to decreased psychological wellbeing and increased risk of alcohol misuse, depression, and obesity [19]. It must be noted that both stereotype threat and internalized racism are likely inherited across generations among minority groups through the transmission of social norms and familial expectations.

Interpersonal racism is another mechanism through which cultural racism is related to adverse health outcomes. Interpersonal racism, though sometimes demonstrated through egregious behaviors such as hate crimes, police brutality, or macroaggressions, is more often rooted in implicit (or unconscious) bias and can manifest during routine social interactions as microaggressions, increased vigilance in public settings, reduced likelihood of obtaining patient-centered care from healthcare providers, and inequitable assessments by instructors or employers. [20,21]. It is important to note that one can be exposed to interpersonal racism either directly or indirectly through the lived experiences of others [22]. In addition to serving as an acute traumatic stressor, especially in the case of egregious or violent behaviors, interpersonal racism also operates as a chronic stressor $[23,24]$. Widespread research has indicated that exposure to chronic stressors, such as interpersonal racism, can significantly increase one's risk of premature mortality and morbidity directly through neuroendocrine (i.e., frequent elevation of one's neuroendocrine responses and resulting increases in cholesterol, blood sugar, triglycerides, and blood pressure) or immune (i.e., impairment of the immune system and subsequent risk of infection) pathways, as well as indirectly through unhealthy behaviors such as poor diet, smoking, alcohol and other substance misuse, risky sexual behaviors, reduced use of preventative services, and decreased compliance with healthcare recommendations [25-35]. Further, chronic stress has been linked to the development of mental health conditions, such as depression and anxiety, which are also inextricably interrelated with physical health outcomes $[33,36,37]$. Importantly, stress resulting from cumulative exposure to interpersonal racism can also be transmitted intergenerationally, in that stress, in terms of both perceived stress and stressful life events, before and during pregnancy have been strongly linked to adverse obstetric outcomes, such as pregnancy complications, low birthweight, and preterm birth, which, in turn, have profound and multifactorial implications for long-term maternal and child health outcomes [38-46].

Structural racism is considered the most insidious form of racism due to its systemic, multifaceted, and multi-generational impacts on health outcomes among communities 
of color. Structural racism has been defined as "policies, laws, and regulations that systematically result in differential access to services and opportunities in society based on race" [20], p. 2. At the core of structural racism may be the "colour-graded hierarchy of citizenship" [12], p. 2, whereby Whiteness fundamentally defines citizenship, and minority groups, such as African Americans, are not socially regarded as equal to Whites, despite nativity status. A potential product of this phenomenon is that U.S.-born Black mothers experience significantly worse obstetric outcomes, such as preterm birth, low birthweight, and infant mortality, when compared to foreign-born Black mothers living in the U.S. [47-49]. This evidence suggests that due to this implicit hierarchy of citizenship, the social, economic, and psychological ramifications of growing up Black in the U.S., as opposed to genetic makeup, places African American communities at higher risk for adverse health outcomes.

Structural racism impacts health through its historical and contemporary influences on equitable access to, and quality of, key social and environmental determinants of health For example, the practice of redlining by the Home Owner's Loan Corporation (HOLC) in the 1930s hindered communities of color from obtaining home mortgages and subsequently, access to public transportation, healthcare, and supermarkets, and has played a vital role in engendering residential segregation in the United States [50-53]. In turn, in communities characterized by widespread residential segregation, African Americans are more likely to live in neighborhoods that have higher levels of poverty, experience reduced access to employment, nutritional, transportation, healthcare, and educational resources and opportunities, and reside in health-inhibiting physical environments [52,54-58]. Beyond the damaging impacts of residential segregation, structural racism has been linked with reduced access to, and quality of, healthcare as well as discriminatory incarceration practices that disadvantage African Americans [50].

Further, as discussed with the example of redlining and its long-lasting implications, the social and health inequities resulting from structural racism are transferred across generations. A related example of how structural racism is transmitted intergenerationally is the inheritance of poverty among African Americans, due to greater exposure to factors such as fewer parental material resources, higher likelihood of an unstable family structure, residential segregation, and fewer neighborhood and community-level resources, all of which originate from the insidious legacy of slavery in the U.S. [59-61]. Further, the intergenerational transmission of risk attributable to structural racism is perhaps most concretely manifested through the increased risk of adverse obstetric outcomes and higher infant mortality rates in African American communities. For instance, research has shown that African American women exposed to residential segregation are more likely to experience adverse birth outcomes, even after controlling for individual and neighborhood-level poverty [58,62-64].

\section{Racism and COVID-19}

The COVID-19 pandemic highlights the discrimination and racism that have long contributed to adverse emotional, mental, and physical health outcomes in African American communities [65]. For example, COVID-19 illuminates medical mistreatment and mistrust in the African American community. Members of racial and ethnic minority groups tend to receive lower quality of care than Whites, contributing to poorer COVID-19 outcomes among African Americans [66]. There have been high-profile cases of denied access to COVID-19 testing among African Americans. A beloved 30-year-old African American teacher died of COVID-19 after twice being denied a COVID-19 test [67]. In another tragedy, a nurse infected on her job of 31 years died after being turned away four times with COVID-19 symptoms [68]. Another man sick with COVID-19 was turned away by three hospitals before he died at home [69]. The death of a high-risk man sent home from a hospital and told to call his doctor to schedule a COVID-19 test highlights testing barriers for Black residents [70]. Research has shown that despite being at increased risk of exposure to the virus and requiring more intensive care at the time they tested positive for 
COVID-19, people of color, particularly African Americans, do not have markedly higher testing rates and face increased barriers to care [71,72].

Moreover, access to COVID-19 testing may depend on where one lives. One investigation found that in four cities in Texas, testing centers were disproportionately located in White communities compared to communities with predominantly Black persons [73]. In other instances, officials have been slow to make testing facilities available and accessible to people living in exclusively Black neighborhoods [74,75]. These factors contribute to greater demand, longer wait times for testing, and increased travel time to testing sites [76,77]. Therefore, African Americans are particularly susceptible to COVID-19 exposure due to disparities in access to care.

Furthermore, the known risk factors for COVID-19 complications need to be examined within the context of adverse social determinants of health that put minority communities at increased risk for disease and mortality. Such factors include, but are not limited to, reduced access to healthy food, housing density, income, education level, occupation, and crowding conditions [9]. The disparate racial impact of COVID-19 also manifests through African American workers facing more economic and health insecurity from COVID-19 than White workers. Patterns of racism and discrimination mean that African Americans have been more likely to be exposed to the virus through work, and less likely to have access to high-quality health care and the resources, such as health insurance, to maintain their health. Racial discrimination in the labor market means that African Americans are more likely to be paid less, overrepresented in jobs that cannot be done from home, terminated, unemployed longer, and to have their unemployment claims denied, compared to their White peers [78]. Effects of the pandemic on African American workers include devastating job losses, spiking unemployment rates, and increased likelihood to be in front-line jobs as essential workers [79].

\section{Social Stigma and COVID-19}

The unparalleled COVID-19 pandemic has intensified the stigma, marginalization, and structural racism that was already devastating African American communities [80]. Stigma has been described as an experience of individuals or communities who are purposely or inevitably excluded from full social approval or who have something unusual or unpleasant exposed about their moral status [81]. In the context of health, stigma can be described as "the negative association between a person or group of people who share certain characteristics and a specific disease" [82]. Stigma is associated with a lack of knowledge about how COVID-19 spreads, fears about disease and death, a need to blame someone, and gossip that spreads rumors and myths. Stigma can also lead to stereotyping, discrimination, labeling, and other negative behaviors toward others [83].

Discriminatory behaviors such as refusal to deliver service, isolation, bullying, and harassment may be experienced by the stigmatized group along with family members, caregivers, those in the same community, or those of the same racial/ethnic group. Such behaviors may obstruct efforts to mitigate disease. This can result in not getting tested due to negative encounters with the healthcare system and not practicing healthy behaviors, such as social distancing, due to lack of paid time off work [84]. Negative healthcare experiences can breed medical mistrust and lead to hesitancy among African Americans to get the COVID-19 vaccine [85]. Discrimination can thwart healthy behaviors if African Americans fear raising police's suspicions for wearing a mask or having the police called on them for not wearing one [86,87]. Perception of COVID-associated discrimination has been associated with race/ethnicity and wearing masks [88]. Moreover, preliminary data show that African Americans are disproportionately arrested for social distancing violations [89], increasing the probability of exposure to the stressor of police presence and potentially deadly encounters [86]. These lived experiences of racism, stigma, and COVID-19 further indicate the hierarchy of citizenship, which was previously discussed in this paper, that African Americans in the U.S. face [12]. 
Groups who suffer stigma may also experience discrimination in the form of being denied healthcare [83]. As discussed, there have been fewer testing sites in African American neighborhoods, suggesting discrimination or bias in testing. Anecdotal and empirical data suggest that African Americans presenting with symptoms of upper respiratory infection (e.g., fever, cough) have been less likely to be tested for COVID-19 compared to Whites, indicating disparate access to immediate testing and treatment [90]. Even after testing positive for COVID-19, many African Americans fear they will not receive life-saving treatment if they suffer severe disease or will be denied care due to discriminatory assumptions about their chances of survival [91].

Fear of contracting COVID-19 is high in African American communities, illustrated by population survey estimates that $33 \%$ of African Americans are very concerned they will contract and be hospitalized with COVID-19, compared to only $18 \%$ of Whites [91]. African Americans are also twice as likely as Whites to know someone who has been hospitalized with or has died from COVID-19 [92]. This can create second-hand trauma when African Americans continually witness the pain and suffering of people who look like them [91]. These factors warrant greater attention to the role of social determinants of health and stigma in COVID-19.

\section{Racism, Stigma, COVID-19, and Health: Proposed Integrated Weathering Framework}

It is clear that the relationships between racism, stigma, COVID-19, and health outcomes among African Americans are dynamic and multifactorial. Thus, developing a comprehensive theoretical model that illustrates these relationships would have substantial implications for future research, programs, and policies to improve the health of African American communities during this critical time. Versions of Bronfenbrenner's socio-ecological model $[93,94]$ have been widely used to conceptualize how the multiple nested determinants of health (i.e., biological, behavioral, psychological, sociocultural, medical, environmental, and political factors) interact with each other and contribute to health and disease risk. Further, the life course model of health [95] conceptualizes health as the result of the cumulative effects of both risky and protective factors and events across the lifespan as well as intergenerational factors. The Weathering Hypothesis, originally developed by Geronimus [96] to explain the significant disparities in adverse birth outcomes among African Americans and Whites, expands on both the socio-ecological and life course models to elucidate the etiology of premature mortality and morbidity among African Americans.

The Weathering Hypothesis theorizes that African Americans experience accelerated biological aging due to cumulative exposures to stressors attributable to adverse social, economic, environmental, and political conditions [97]. This hypothesis further posits that frequent exposures to stressors result in continuous, "high-effort" coping responses at the physiological level, which, in turn, negatively affect health [97], p. 826. Importantly, the Weathering Hypothesis helps explain not only premature mortality and morbidity among African Americans, but also the widening health disparities among African Americans and Whites as age increases. For example, Geronimus' seminal research discovered that the established curvilinear relationship between maternal age and adverse birth outcomes (i.e., teenagers and older women experiencing a higher risk of unfavorable birth outcomes than women in their 20s) did not hold for African American women; instead, teenage African American mothers experienced better birth outcomes when compared to their older counterparts [96,98-100]. Moreover, a systematic review by Forde et al. [98] found widespread empirical evidence supporting the role of weathering in contributing to adverse obstetric outcomes (e.g., decreased infant birthweight, preterm birth, intrauterine growth retardation, infant mortality) and chronic health conditions (e.g., diabetes, hypertension, cardiovascular disease, anemia).

Overall, the Weathering Hypothesis comprehensively connects the socio-ecological model with the life course model to illustrate the significantly disparate health trajectories that African Americans and Whites experience, and it has also been heavily supported in 
research studies during the past few decades. Therefore, we propose an integrated Weathering Framework to depict predicted relationships between racism, stigma, COVID-19, and health outcomes among African Americans. In the conceptual diagram (Figure 1), the blue arrows represent proposed causative links, the yellow arrows denote proposed bidirectional relationships, and the purple dotted arrows signify proposed modifying relationships. At the crux of this framework and as substantiated in the literature, racism (including cultural, structural, and interpersonal forms of racism) is a root cause of diminished health and wellbeing among African Americans. We posit that racism operates through, or interacts with, the multiple determinants of health to yield both acute and chronic experiences of stress. In other words, the determinants of health likely partially mediate the associations between racism and stress; additionally, the experience of racism also likely modifies the impacts of negative determinants of health, thus leading to increased stress. In the proposed framework, we also acknowledge that repeated exposures to interpersonal racism are directly associated with chronic stress [22,24].

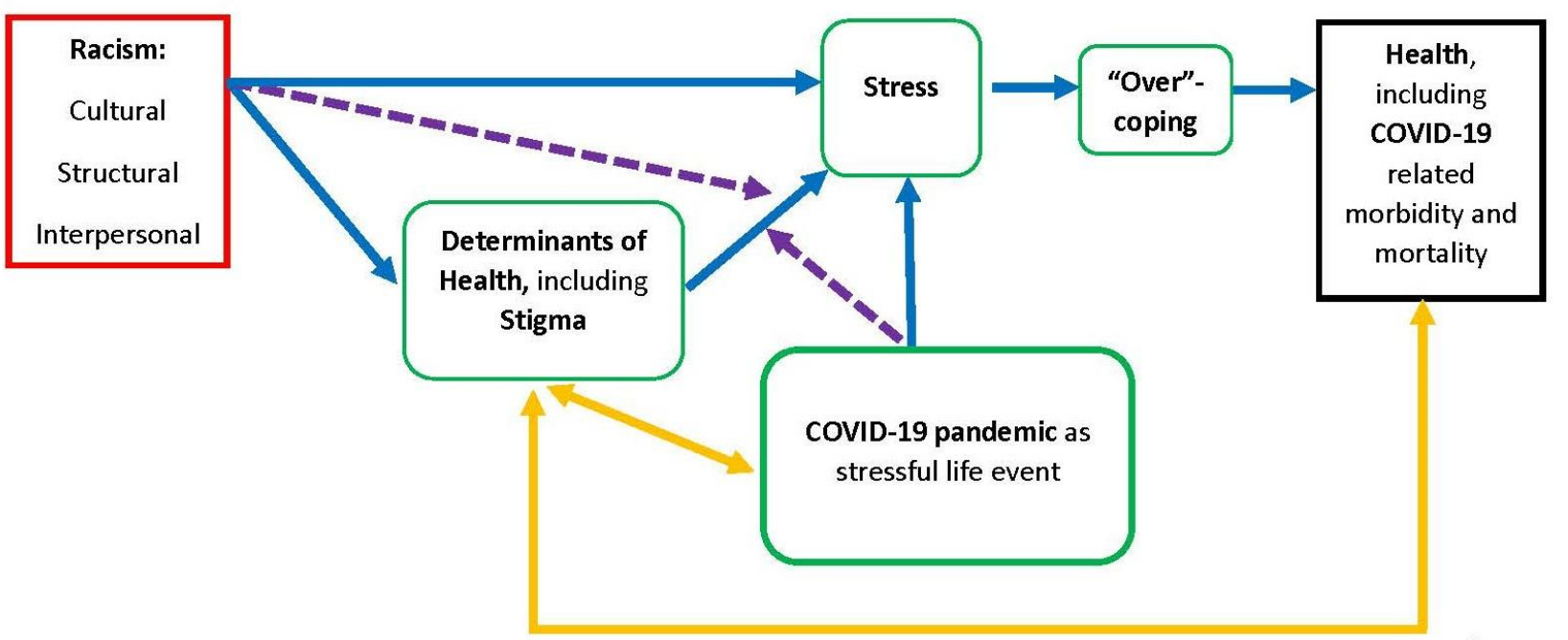

Life Course

\begin{tabular}{|l} 
Legend: \\
$\square$ Primary predictor variable \\
$\square$ Primary outcome variable \\
$\square$ Intervening variable \\
$\square$ Proposed causative relationship \\
$\square$ Proposed bidirectional relationship \\
\hline- Proposed modifying relationship
\end{tabular}

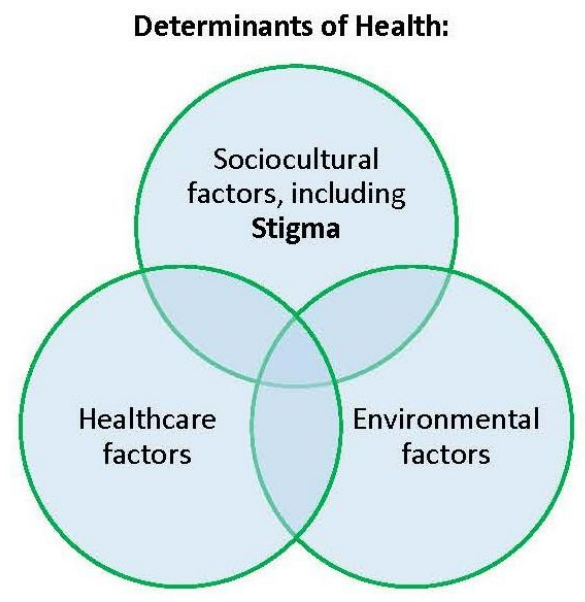

Figure 1. Application of Integrated Weathering Framework: Proposed Relationships between Racism, Stigma, COVID-19 and Health Outcomes Among African Americans.

Based on the socio-ecological model, these multiple determinants of health are inextricably interrelated and are nested within individual, interpersonal, community, and broader systemic factors $[93,94]$. Specifically, determinants of health comprise sociocultural factors, including socioeconomic status, gender, race, ethnicity, and stigma as well as access to and quality of education, employment, housing, transportation, and food/nutrition; healthcare 
factors such as quality of, access to, and coordination of healthcare as well as health literacy; and environmental factors, including characteristics of the surrounding physical environment and safety. Our proposed conceptual framework indicates bidirectional relationships between the determinants of health and health outcomes. The framework embodies the life course model by emphasizing that the accumulation of risky and protective exposures to these multiple determinants of health over the life course directly impact one's health outcomes, including COVID-19-related mortality and morbidity. Further, we posit that one's health status also likely impacts one's sociocultural, healthcare, and environmental conditions and opportunities, thereby perpetuating the cycle by which the most vulnerable individuals experience worsening outcomes over the life course. For example, individuals with chronic illnesses as well as their families are more likely to experience greater socioeconomic burdens such as higher healthcare expenditures, reduced likelihood of obtaining or sustaining full-time employment, and decreased educational attainment [101-103].

Moreover, we hypothesize that as individuals experience frequent exposures to acute and chronic stressors, rooted in racism and negative determinants of health, over the life course, they physiologically adapt to their circumstances by "over-coping," or the high-effort coping described by Geronimus. Research studies have tested the Weathering Hypothesis by exploring various biological mechanisms linking broader determinants of health to disparities in health outcomes. The majority of biomarkers, such as cortisol [104], sympathetic nerve activity [105], blood pressure reactivity [106,107], cytokine production [108], and glycated hemoglobin $[109,110]$, used in these studies are either direct or potential indicators of physiological stress responses [98]. In terms of the next component of our proposed framework, over-coping likely impacts health outcomes through the accumulation of allostatic load, a construct coined by McEwen and Seeman [111]. Allostatic load is broadly described as the "cumulative wear and tear on the body's systems owing to repeated adaptation to stressors" [97], p. 826. Additionally, based on findings from a multitude of studies, shortened cellular telomere length, a biomarker for aging [112], is significantly associated with chronic physical and mental health deterioration and mortality [113-115] as well as stress and stressors (i.e., childhood trauma, stressful life events) [116-119]. Therefore, the shortening of telomere length is considered to be a potential biological mechanism through which stress and the consequent accumulation of allostatic load impact health outcomes and lead to accelerated aging, per the Weathering Hypothesis. Importantly, many research studies have found that perceived racism and discrimination are significantly associated with shortened telomere length among African Americans [120-123], thereby further substantiating our proposed Weathering Framework. In addition to the neuroendocrine and immune system pathways that directly link stress and health outcomes, widespread research indicates that exposure to stress may also entail "over-coping" through unhealthy behaviors, including poor diet, tobacco, alcohol and other substance misuse, and risky sexual behaviors, which are, in turn, associated with adverse health outcomes [124-133].

Finally, we posit that COVID-19 plays two key roles in the proposed conceptual framework. First, a COVID-19 diagnosis is a health outcome, and widespread evidence has indicated that African Americans have significantly higher rates of COVID-19 cases as well as greater case-fatalities when compared to Whites [8-10]. Second, we envision the COVID-19 pandemic, regardless of disease status, as a stressful life event that results in experiences of stress [134-136] and has a bidirectional relationship with the determinants of health, including stigma. Specifically, pandemic-related effects that are particularly salient among communities of color and other vulnerable populations have included negative determinants of health, such as unemployment or underemployment, increased isolation, reduced educational opportunities, postponement of preventive care needs, reduced access to public transportation as well as free or subsidized meals, and increased stigma related to racial or cultural identity [137-139]. Further, we hypothesize that vulnerable individuals who have already experienced chronic exposures to the negative determinants of health over the life course will be more likely to perceive the pandemic as stressful, as they may 
not have adequate protective resources or conditions to withstand the adverse impacts of the pandemic without experiencing significant health implications in the long term. Along these lines, we also posit that COVID-19, as a stressful life event, potentially modifies the relationship between the determinants of health and stress, in that it may render more pronounced impacts among these aforementioned vulnerable individuals, when compared to individuals who are exposed to favorable determinants of health, and place them at greater risk for experiencing both acute and chronic stress. Overall, our Weathering Framework theorizes that COVID-19 not only operates as a potential health outcome but also operates as a critical stressful life event that exacerbates existing physical and mental health disparities, which are rooted in racism and related to the multiple determinants of health.

\section{Implications and Future Directions}

The existence of racism as a root cause of COVID-19 health disparities among African Americans, as described in the proposed Weathering Framework, necessitates the expansion and continuation of programs, clinical interventions, policies, and further research to improve health equity. Public health officials and community leaders can help prevent stigma by using media channels, including social media and news media, to denounce the stereotyping of groups of people who experience stigma because of COVID-19 [83]. Fostering culturally tailored behavioral and mental health dialogue and responses should help promote proactive self-care, reduce stigma, and encourage integrated health care [8]. Developing comprehensive national programs to provide integrated health care to the underinsured and uninsured impacted by COVID-19 would promote increased resiliency within African American communities and reduce their susceptibility to adverse outcomes and long-term socioeconomic hardships [14]. Clinical care providers must be cognizant of the historical mistrust of medical providers and public officials that may increase the emotional needs of African Americans and ensure collaborative treatment to help strengthen patient buy-in [140]. Importantly, in terms of both clinical and programmatic settings, there is a critical need to increase diversity in the workforce, including the incorporation of community health workers, in order to strengthen provider-client relationships and help community residents feel more comfortable, connected, and empowered while obtaining health and human services [20,141,142].

Policy options and action opportunities to close the health equity gap include working towards universal healthcare coverage with particular attention to social and cultural barriers. This can be achieved by expanding the availability of comprehensive primary and secondary services, which address the multiple determinants of health, in minority communities, and by improving coordination between levels of care. Strategies should be tested and evaluated to extend access to and ensure quality care for minority communities, with provisions that stigmatization and inequities are not reinforced. Other strategies include promoting ongoing engagement among multiple sectors to institutionalize health equity goals and collecting data that measures racial inequities in health to provide the foundation for political action and accountability on the determinants of health and the advancement of health equity [143]. Furthermore, addressing health disparities will require a multifaceted approach from diverse stakeholders, including academic institutions [144]. Therefore, solutions are needed to enhance community engagement among stakeholders of African American health, augment population and public health funding to promote health equity among African Americans, and increase the number of African American healthcare providers [80]. These efforts may help mitigate the negative effects of hierarchy of citizenship [12] that exist among communities of color in the U.S.

The proposed conceptual framework also has important implications for future research directions. First, we recommend that longitudinal studies investigate the independent and combined impacts of racism and COVID-19, as a pandemic and as a diagnosis, on long-term mental and physical health outcomes across the life course as well as the societal and biological mechanisms through which these impacts occur. Second, large-scale 
research studies must link various sources of data, including population-based observational studies, vital statistics, census data, health insurance claims databases, and other administrative data, to simultaneously examine the multiple determinants of health and their complex interactions with COVID-19 among communities of color. Gaining insight into the relationships between racism, COVID-19, and the multiple determinants of health will enable community stakeholders to develop more coordinated responses, comprising strategic partnerships among public, private, health, and non-health-related sectors, to the pandemic; these responses should ideally entail intentionally anti-racist programmatic, clinical and policy interventions as well as long-term systemic changes in the community infrastructure that promote health equity. Importantly, we posit that researchers, program developers, and policymakers can also employ lessons learned from utilizing our proposed integrated Weathering Framework to examine and mitigate the adverse impacts of future population health crises, such as natural disasters, communicable disease epidemics, and environmental health emergencies, among communities of color and other vulnerable populations.

\section{Conclusions}

The disproportionate impact of COVID-19 on African American communities necessitates a deeper exploration of the intersectional roles of racism, stigma, and other social determinants of health in influencing disease and mortality risk. In this paper, we developed and applied an integrated Weathering Framework to illustrate the dynamic interrelationships between these critical factors and conceptualized COVID-19 as a stressful life event that will have profound health implications over the life course for African Americans. The proposed Weathering Framework, which explores the role of racism as a root cause of COVID-19 health disparities among African Americans, can be employed to inform future population health and clinical interventions, policies, and continued research to improve health equity.

Author Contributions: Conceptualization, F.W. and A.N.; development of theoretical framework, F.W.; literature review, F.W. and A.N.; writing—original draft preparation, F.W. and A.N.; writingreview and editing, F.W. and A.N. All authors have read and agreed to the published version of the manuscript.

Funding: This research received no external funding.

Institutional Review Board Statement: Not applicable.

Informed Consent Statement: Not applicable.

Data Availability Statement: No new data were created or analyzed in this study. Data sharing is not applicable to this article.

Conflicts of Interest: The authors declare no conflict of interest.

\section{References}

1. Sohrabi, C.; Alsafi, Z.; O’Neill, N.; Khan, M.; Kerwan, A.; Al-Jabir, A.; Iosifidis, C.; Agha, R. World Health Organization Declares Global Emergency: A Review of the 2019 Novel Coronavirus (COVID-19). Int. J. Surg. 2020, 76, 71-76. [CrossRef] [PubMed]

2. Young, B.E.; Ong, S.W.X.; Kalimuddin, S.; Low, J.G.; Tan, S.Y.; Loh, J.; Ng, O.-T.; Marimuthu, K.; Ang, L.W.; Mak, T.M.; et al. Epidemiologic Features and Clinical Course of Patients Infected with SARS-CoV-2 in Singapore. JAMA 2020, 323, 1488. [CrossRef] [PubMed]

3. Zhu, N.; Zhang, D.; Wang, W.; Li, X.; Yang, B.; Song, J.; Zhao, X.; Huang, B.; Shi, W.; Lu, R.; et al. A Novel Coronavirus from Patients with Pneumonia in China, 2019. N. Engl. J. Med. 2020, 382, 727-733. [CrossRef] [PubMed]

4. COVID-19 Map. Available online: https:// coronavirus.jhu.edu/map.html (accessed on 16 December 2020).

5. Coronavirus Update (Live): 72,103,223 Cases and 1,611,492 Deaths from COVID-19 Virus Pandemic-Worldometer. Available online: https:/ / www.worldometers.info/coronavirus/ (accessed on 16 December 2020).

6. CDC. COVID-19 Cases, Deaths, and Trends in the US I CDC COVID Data Tracker. Available online: https:/ /covid.cdc.gov/coviddata-tracker (accessed on 16 December 2020).

7. CDC. COVID-19 and Your Health: People with Certain Medical Conditions. Available online: https://www.cdc.gov/coronavirus / 2019-ncov/need-extra-precautions/people-with-medical-conditions.html (accessed on 18 November 2020). 
8. Henry Akintobi, T.; Jacobs, T.; Sabbs, D.; Holden, K.; Braithwaite, R.; Johnson, L.N.; Dawes, D.; Hoffman, L. Community Engagement of African Americans in the Era of COVID-19: Considerations, Challenges, Implications, and Recommendations for Public Health. Prev. Chronic Dis. 2020, 17, 200255. [CrossRef] [PubMed]

9. Yancy, C.W. COVID-19 and African Americans. JAMA 2020, 323, 1891. [CrossRef] [PubMed]

10. Millett, G.A.; Jones, A.T.; Benkeser, D.; Baral, S.; Mercer, L.; Beyrer, C.; Honermann, B.; Lankiewicz, E.; Mena, L.; Crowley, J.S.; et al. Assessing Differential Impacts of COVID-19 on Black Communities. Ann. Epidemiol. 2020, 47, 37-44. [CrossRef] [PubMed]

11. CDC. Coronavirus Disease 2019 (COVID-19). Available online: https://www.cdc.gov/coronavirus/2019-ncov/covid-data/ investigations-discovery/hospitalization-death-by-race-ethnicity.html (accessed on 16 December 2020).

12. Lazarus, S. 'Some Animals Are More Equal Than Others': The Hierarchy of Citizenship in Austria. Laws 2019, 8, 14. [CrossRef]

13. Egede, L.E.; Walker, R.J. Structural Racism, Social Risk Factors, and Covid-19-A Dangerous Convergence for Black Americans. N. Engl. J. Med. 2020, 383, e77. [CrossRef]

14. Novacek, D.M.; Hampton-Anderson, J.N.; Ebor, M.T.; Loeb, T.B.; Wyatt, G.E. Mental Health Ramifications of the COVID-19 Pandemic for Black Americans: Clinical and Research Recommendations. Psychol. Trauma Theory Res. Pract. Policy 2020, 12, 449-451. [CrossRef]

15. Hicken, M.T.; Kravitz-Wirtz, N.; Durkee, M.; Jackson, J.S. Racial Inequalities in Health: Framing Future Research. Soc. Sci. Med. 2018, 199, 11-18. [CrossRef]

16. Williams, D.R.; Mohammed, S.A. Racism and Health I: Pathways and Scientific Evidence. Am. Behav. Sci. 2013, 57, 1152-1173. [CrossRef] [PubMed]

17. Williams, D.R.; Lawrence, J.A.; Davis, B.A. Racism and Health: Evidence and Needed Research. Annu. Rev. Public Health 2019, 40, 105-125. [CrossRef] [PubMed]

18. Spencer, S.J.; Logel, C.; Davies, P.G. Stereotype Threat. Annu. Rev. Psychol. 2016, 67, 415-437. [CrossRef] [PubMed]

19. Williams, D.R.; Mohammed, S.A. Discrimination and Racial Disparities in Health: Evidence and Needed Research. J. Behav. Med. 2009, 32, 20-47. [CrossRef] [PubMed]

20. Johnson, T.J. Intersection of Bias, Structural Racism, and Social Determinants With Health Care Inequities. Pediatrics 2020, 146, e2020003657. [CrossRef] [PubMed]

21. Jones, C.P. Levels of Racism: A Theoretic Framework and a Gardener's Tale. Am. J. Public Health 2000, 90, 1212-1215. [CrossRef] [PubMed]

22. Harrell, S.P. A Multidimensional Conceptualization of Racism-Related Stress: Implications for the Well-Being of People of Color. Am. J. Orthopsychiatry 2000, 70, 42-57. [CrossRef] [PubMed]

23. Clark, R.; Anderson, N.B.; Clark, V.R.; Williams, D.R. Racism as a Stressor for African Americans: A Biopsychosocial Model. Am. Psychol. 1999, 54, 805-816. [CrossRef]

24. Brondolo, E.; ver Halen, N.B.; Libby, D.; Pencille, M. Racism as a Psychosocial Stressor. In The Handbook of Stress Science: Biology, Psychology, and Health; Springer Publishing Company: New York, NY, USA, 2011; pp. 167-184.

25. Borrell, L.N.; Jacobs, D.R.; Williams, D.R.; Pletcher, M.J.; Houston, T.K.; Kiefe, C.I. Self-Reported Racial Discrimination and Substance Use in the Coronary Artery Risk Development in Adults Study. Am. J. Epidemiol. 2007, 166, 1068-1079. [CrossRef]

26. Brondolo, E.; Rieppi, R.; Kelly, K.P.; Gerin, W. Perceived Racism and Blood Pressure: A Review of the Literature and Conceptual and Methodological Critique. Ann. Behav. Med. 2003, 25, 55-65. [CrossRef]

27. Casagrande, S.S.; Gary, T.L.; LaVeist, T.A.; Gaskin, D.J.; Cooper, L.A. Perceived Discrimination and Adherence to Medical Care in a Racially Integrated Community. J. Gen. Intern. Med. 2007, 22, 389-395. [CrossRef] [PubMed]

28. Choi, Y.; Harachi, T.W.; Gillmore, M.R.; Catalano, R.F. Are Multiracial Adolescents at Greater Risk? Comparisons of Rates, Patterns, and Correlates of Substance Use and Violence between Monoracial and Multiracial Adolescents. Am. J. Orthopsychiatry 2006, 76, 86-97. [CrossRef] [PubMed]

29. Harrell, J.P.; Hall, S.; Taliaferro, J. Physiological Responses to Racism and Discrimination: An Assessment of the Evidence. Am. J. Public Health 2003, 93, 243-248. [CrossRef] [PubMed]

30. Hausmann, L.R.M.; Jeong, K.; Bost, J.E.; Ibrahim, S.A. Perceived Discrimination in Health Care and Use of Preventive Health Services. J. Gen. Intern. Med. 2008, 23, 1679-1684. [CrossRef] [PubMed]

31. Landrine, H.; Klonoff, E.A. Racial Discrimination and Cigarette Smoking among Blacks: Findings from Two Studies. Ethn. Dis. 2000, 10, 195-202. [PubMed]

32. Mouzon, D.M.; Taylor, R.J.; Woodward, A.T.; Chatters, L.M. Everyday Racial Discrimination, Everyday Non-Racial Discrimination, and Physical Health Among African-Americans. J. Ethn. Cult. Divers. Soc. Work 2017, 26, 68-80. [CrossRef] [PubMed]

33. Paradies, Y. A Systematic Review of Empirical Research on Self-Reported Racism and Health. Int. J. Epidemiol. 2006, 35, 888-901. [CrossRef]

34. Thrasher, A.D.; Earp, J.A.L.; Golin, C.E.; Zimmer, C.R. Discrimination, Distrust, and Racial/Ethnic Disparities in Antiretroviral Therapy Adherence Among a National Sample of HIV-Infected Patients. JAIDS J. Acquir. Immune Defic. Syndr. 2008, 49, 84-93. [CrossRef]

35. Trivedi, A.N.; Ayanian, J.Z. Perceived Discrimination and Use of Preventive Health Services. J. Gen. Intern. Med. 2006, 21, 553-558. [CrossRef]

36. Taylor, J.; Turner, R.J. Perceived Discrimination, Social Stress, and Depression in the Transition to Adulthood: Racial Contrasts. Soc. Psychol. Q. 2002, 65, 213. [CrossRef] 
37. Williams, D.R.; Williams-Morris, R. Racism and Mental Health: The African American Experience. Ethn. Health 2000, 5, 243-268. [CrossRef] [PubMed]

38. Collins, J.W.; David, R.J.; Symons, R.; Handler, A.; Wall, S.N.; Dwyer, L. Low-Income African-American Mothers' Perception of Exposure to Racial Discrimination and Infant Birth Weight. Epidemiology 2000, 11, 337-339. [CrossRef] [PubMed]

39. Collins, J.W.; David, R.J.; Handler, A.; Wall, S.; Andes, S. Very Low Birthweight in African American Infants: The Role of Maternal Exposure to Interpersonal Racial Discrimination. Am. J. Public Health 2004, 94, 2132-2138. [CrossRef] [PubMed]

40. Dole, N.; Savitz, D.A.; Siega-Riz, A.M.; Hertz-Picciotto, I.; McMahon, M.J.; Buekens, P. Psychosocial Factors and Preterm Birth among African American and White Women in Central North Carolina. Am. J. Public Health 2004, 94, 1358-1365. [CrossRef] [PubMed]

41. Giscombé, C.L.; Lobel, M. Explaining Disproportionately High Rates of Adverse Birth Outcomes among African Americans: The Impact of Stress, Racism, and Related Factors in Pregnancy. Psychol. Bull. 2005, 131, 662-683. [CrossRef]

42. Hobel, C.; Culhane, J. Role of Psychosocial and Nutritional Stress on Poor Pregnancy Outcome. J. Nutr. 2003, 133, 1709S-1717S. [CrossRef]

43. Lauderdale, D.S. Birth Outcomes for Arabic-Named Women in California before and after September 11. Demography 2006, 43, 185-201. [CrossRef]

44. Mustillo, S.; Krieger, N.; Gunderson, E.P.; Sidney, S.; McCreath, H.; Kiefe, C.I. Self-Reported Experiences of Racial Discrimination and Black-White Differences in Preterm and Low-Birthweight Deliveries: The CARDIA Study. Am. J. Public Health 2004, 94, 2125-2131. [CrossRef]

45. Rosenberg, L.; Palmer, J.R.; Wise, L.A.; Horton, N.J.; Corwin, M.J. Perceptions of Racial Discrimination and the Risk of Preterm Birth. Epidemiology 2002, 13, 646-652. [CrossRef]

46. Witt, W.P.; Litzelman, K.; Cheng, E.R.; Wakeel, F.; Barker, E.S. Measuring Stress Before and During Pregnancy: A Review of Population-Based Studies of Obstetric Outcomes. Matern. Child Health J. 2014, 18, 52-63. [CrossRef]

47. Hummer, R.A.; Biegler, M.; Turk, P.B.D.; Forbes, D.; Frisbie, W.P.; Hong, Y.; Pullum, S.G. Race/Ethnicity, Nativity, and Infant Mortality in the United States. Soc. Forces 1999, 77, 1083. [CrossRef]

48. Kramer, M.S.; Ananth, C.V.; Platt, R.W.; Joseph, K. US Black vs White Disparities in Foetal Growth: Physiological or Pathological? Int. J. Epidemiol. 2006, 35, 1187-1195. [CrossRef]

49. Acevedo-Garcia, D.; Soobader, M.-J.; Berkman, L.F. The Differential Effect of Foreign-Born Status on Low Birth Weight by Race/Ethnicity and Education. Pediatrics 2005, 115, e20-e30. [CrossRef] [PubMed]

50. Bailey, Z.D.; Krieger, N.; Agénor, M.; Graves, J.; Linos, N.; Bassett, M.T. Structural Racism and Health Inequities in the USA: Evidence and Interventions. Lancet 2017, 389, 1453-1463. [CrossRef]

51. Hillier, A.E. Redlining and the Home Owners' Loan Corporation. J. Urban Hist. 2003, 29, 394-420. [CrossRef]

52. Williams, D.R.; Collins, C. Racial Residential Segregation: A Fundamental Cause of Racial Disparities in Health. Public Health Rep. 2001, 116, 404-416. [CrossRef]

53. Yearby, R. Racial Disparities in Health Status and Access to Healthcare: The Continuation of Inequality in the United States Due to Structural Racism: Continuing Racial Health Disparities. Am. J. Econ. Sociol. 2018, 77, 1113-1152. [CrossRef]

54. Kramer, M.R.; Hogue, C.R. Is Segregation Bad for Your Health? Epidemiol. Rev. 2009, 31, 178-194. [CrossRef]

55. Mays, V.M.; Cochran, S.D.; Barnes, N.W. Race, Race-Based Discrimination, and Health Outcomes among African Americans. Annu. Rev. Psychol. 2007, 58, 201-225. [CrossRef]

56. Schulz, A.J.; Kannan, S.; Dvonch, J.T.; Israel, B.A.; Allen, A.; James, S.A.; House, J.S.; Lepkowski, J. Social and Physical Environments and Disparities in Risk for Cardiovascular Disease: The Healthy Environments Partnership Conceptual Model. Environ. Health Perspect. 2005, 113, 1817-1825. [CrossRef]

57. Schulz, A.J.; Williams, D.R.; Israel, B.A.; Lempert, L.B. Racial and Spatial Relations as Fundamental Determinants of Health in Detroit. Milbank Q. 2002, 80, 677-707. [CrossRef] [PubMed]

58. White, K.; Borrell, L.N. Racial/Ethnic Residential Segregation: Framing the Context of Health Risk and Health Disparities. Health Place 2011, 17, 438-448. [CrossRef] [PubMed]

59. Bird, K. The Intergenerational Transmission of Poverty: An Overview. In Chronic Poverty; Shepherd, A., Brunt, J., Eds.; Palgrave Macmillan UK: London, UK, 2013; pp. 60-84. [CrossRef]

60. Corcoran, M. Rags to Rags: Poverty and Mobility in the United States. Annu. Rev. Sociol. 1995, 21, 237-267. [CrossRef]

61. O'Connell, H.A.; Curtis, K.J.; DeWaard, J. Population Change and the Legacy of Slavery. Soc. Sci. Res. 2020, 87, 102413. [CrossRef]

62. Iceland, J.; Wilkes, R. Does Socioeconomic Status Matter? Race, Class, and Residential Segregation. Soc. Probl. 2006, 53, 248-273. [CrossRef]

63. Mehra, R.; Boyd, L.M.; Ickovics, J.R. Racial Residential Segregation and Adverse Birth Outcomes: A Systematic Review and Meta-Analysis. Soc. Sci. Med. 2017, 191, 237-250. [CrossRef]

64. Ncube, C.N.; Enquobahrie, D.A.; Albert, S.M.; Herrick, A.L.; Burke, J.G. Association of Neighborhood Context with Offspring Risk of Preterm Birth and Low Birthweight: A Systematic Review and Meta-Analysis of Population-Based Studies. Soc. Sci. Med. 2016, 153, 156-164. [CrossRef]

65. Rose, S.A. Research Roundup: How COVID-19 Impacts African Americans. Available online: https://www.apaservices.org/ practice/ce/expert/covid-19-african-americans (accessed on 23 November 2020).

66. Laurencin, C.T.; Walker, J.M. A Pandemic on a Pandemic: Racism and COVID-19 in Blacks. Cell Syst. 2020, 11, 9-10. [CrossRef] 
67. Mitropoulos, A.; Moseley, M. Beloved Brooklyn Teacher, 30, Dies of Coronavirus after She Was Twice Denied a COVID-19 Test. Available online: https://abcnews.go.com/Health/beloved-brooklyn-teacher-30-dies-coronavirus-denied-covid/story?id=70 376445 (accessed on 22 November 2020).

68. Beaumont Worker Turned Away 4 Times with COVID-19 Symptoms before Dying. Available online: https:/ /www.fox2detroit. $\mathrm{com} /$ news/beaumont-worker-turned-away-4-times-with-covid-19-symptoms-before-dying (accessed on 22 November 2020).

69. Shamus, K.J. Family Ravaged by Coronavirus Begged for Tests, Hospital Care But Was Repeatedly Denied. Available online: https:/ / www.usatoday.com/story/news/nation/2020/04/20/coronavirus-racial-disparity-denied-tests-hospitalization/51 63056002/ (accessed on 22 November 2020).

70. Basler, C. Son's Death Highlights Testing Barriers for Black Residents. Available online: https://www.wshu.org/post/sonsdeath-highlights-testing-barriers-black-residents (accessed on 22 November 2020).

71. Lieberman-Cribbin, W.; Tuminello, S.; Flores, R.M.; Taioli, E. Disparities in COVID-19 Testing and Positivity in New York City. Am. J. Prev. Med. 2020, 59, 326-332. [CrossRef]

72. Rubin-Miller, L.; Alban, C.; Artiga, S. COVID-19 Racial Disparities in Testing, Infection, Hospitalization, and Death: Analysis of Epic Patient Data-Issue Brief; KFF: San Francisco, CA, USA, 2020.

73. McMinn, S.; Carlsen, A.; Jaspers, B.; Talbot, R.; Adeline, S. In Large Texas Cities, Access to Coronavirus Testing May Depend on Where You Live. Available online: https:/ /www.npr.org/sections/health-shots/2020/05/27/862215848/across-texas-black-andhispanic-neighborhoods-have-fewer-coronavirus-testing-sit (accessed on 22 November 2020).

74. Farmer, B. The Coronavirus Doesn't Discriminate, but U.S. Health Care Showing Familiar Biases. Available online: https: / / www.npr.org/sections/health-shots/2020/04/02/825730141/the-coronavirus-doesnt-discriminate-but-u-s-healthcare-showing-familiar-biases (accessed on 22 November 2020).

75. Peak, C. How Washington, D.C., Mishandled Its Response to the Coronavirus. Available online: https://www.apmreports.org/ story / 2020/07/15/washington-dc-response-to-coronavirus (accessed on 22 November 2020).

76. Artiga, S.; Corallo, B.; Pham, O. Racial Disparities in COVID-19: Key Findings from Available Data and Analysis—Issue Brief; KFF: San Francisco, CA, USA, 2020.

77. Vann, M.; Kim, S.K.; Bronner, L. COVID-19 Test Access Disparities in Some South Florida Communities Fall along Racial, Socioeconomic Lines: ANALYSIS. Available online: https:/ /abcnews.go.com/Politics/ covid-19-test-access-disparities-southflorida-communities/story?id=71884733 (accessed on 28 November 2020).

78. Liu, J. Just 13\% of Black People out of Work Are Getting Unemployment Benefits during the Pandemic. Available online: https:// www.cnbc.com/2020/09/01/just-13percent-of-black-people-out-of-work-get-pandemic-unemployment-benefits.html (accessed on 28 November 2020).

79. Gould, E.; Wilson, V. Black Workers Face Two of the Most Lethal Preexisting Conditions for Coronavirus—Racism and Economic Inequality; Economic Policy Institute: Washington, DC, USA, 2020.

80. Nydegger, L.A.; Hill, M.J. Examining COVID-19 and HIV: The Impact of Intersectional Stigma on Short- and Long-Term Health Outcomes among African Americans. Int. Soc. Work 2020, 63, 655-659. [CrossRef]

81. Goffman, E. Stigma: Notes on the Management of Spoiled Identity; Touchstone: New York, NY, USA, 2014.

82. World Health Organization. A Guide to Preventing and Addressing Social Stigma Associated with COVID-19. Available online: https:/ / www.who.int/publications/m/item/a-guide-to-preventing-and-addressing-social-stigma-associated-withcovid-19 (accessed on 26 November 2020).

83. CDC. COVID-19 and Your Health: Reducing Stigma. Available online: https://www.cdc.gov/coronavirus/2019-ncov/daily-lifecoping/reducing-stigma.html (accessed on 26 November 2020).

84. Turner-Musa, J.; Ajayi, O.; Kemp, L. Examining Social Determinants of Health, Stigma, and COVID-19 Disparities. Healthcare 2020, 8, 168. [CrossRef] [PubMed]

85. Gramlich, J.; Funk, C. Black Americans Face Higher COVID-19 Risks, Are More Hesitant to Trust Medical Scientists, Get Vaccinated; Pew Research Center: Washington, DC, USA, 2020.

86. Rouhandeh, A.J. Social Distancing, Racism, and Protecting People in a Pandemic Without the Police-The American Prospect. Available online: https:/ / prospect.org/coronavirus/social-distancing-racism-protecting-people-without-police/ (accessed on 26 November 2020).

87. Njoku, A.; Ahmed, Y.; Bolaji, B. Police Brutality against Blacks in the United States and Ensuing Protests: Implications for Social Distancing and Black Health during COVID-19. J. Hum. Behav. Soc. Environ. 2020, 1-9. [CrossRef]

88. Liu, Y.; Finch, B.K.; Brenneke, S.G.; Thomas, K.; Le, P.D. Perceived Discrimination and Mental Distress Amid the COVID-19 Pandemic: Evidence From the Understanding America Study. Am. J. Prev. Med. 2020, 59, 481-492. [CrossRef] [PubMed]

89. Kaplan, J.; Hardy, B. Early Data Shows Black People Are Being Disproportionally Arrested for Social Distancing Violations. Available online: https:/ / www.propublica.org/article/in-some-of-ohios-most-populous-areas-black-people-were-at-least-4times-as-likely-to-be-charged-with-stay-at-home-violations-as-whites?token=aA91RugYQlkPCYvk_Z6E9tDkP_5srI8X (accessed on 26 November 2020).

90. Health Data in the COVID-19 Crisis: How Racial Equity Is Widening for Patients to Gain Access to Treatment. Available online: https: / /rubixls.com/2020/04/01/health-data-in-the-covid-19-crisis-how-racial-equity-is-widening-for-patients-togain-access-to-treatment/ (accessed on 27 November 2020). 
91. Sneed, R.S.; Key, K.; Bailey, S.; Johnson-Lawrence, V. Social and Psychological Consequences of the COVID-19 Pandemic in African-American Communities: Lessons from Michigan. Psychol. Trauma Theory Res. Pract. Policy 2020, 12, 446-448. [CrossRef] [PubMed]

92. Pew Research Center; Suite 800Washington; Inquiries, D. 20036USA202-419-4300 | M.-857-8562 | F.-419-4372 | M. Health Concerns from COVID-19 Much Higher among Hispanics and Blacks than Whites. Pew Research Center-U.S. Politics \& Policy. 2020. Available online: https:/ / www.pewresearch.org/politics/2020/04/14/health-concerns-from-covid-19-much-higher-amonghispanics-and-blacks-than-whites / (accessed on 27 November 2020).

93. Bronfenbrenner, U. Toward an Experimental Ecology of Human Development. Am. Psychol. 1977, 32, 513-531. [CrossRef]

94. Bronfenbrenner, U. The Ecology of Human Development: Experiments by Nature and Design; Harvard University Press: Cambridge, MA, USA, 1979.

95. Halfon, N.; Hochstein, M. Life Course Health Development: An Integrated Framework for Developing Health, Policy, and Research. Milbank Q. 2002, 80, 433-479. [CrossRef]

96. Geronimus, A.T. The Weathering Hypothesis and the Health of African-American Women and Infants: Evidence and Speculations. Ethn. Dis. 1992, 2, 207-221.

97. Geronimus, A.T.; Hicken, M.; Keene, D.; Bound, J. “Weathering” and Age Patterns of Allostatic Load Scores Among Blacks and Whites in the United States. Am. J. Public Health 2006, 96, 826-833. [CrossRef]

98. Forde, A.T.; Crookes, D.M.; Suglia, S.F.; Demmer, R.T. The Weathering Hypothesis as an Explanation for Racial Disparities in Health: A Systematic Review. Ann. Epidemiol. 2019, 33, 1-18.e3. [CrossRef]

99. Geronimus, A.T. On Teenage Childbearing and Neonatal Mortality in the United States. Popul. Dev. Rev. 1987, 13, 245. [CrossRef]

100. Geronimus, A.T. Black/White Differences in the Relationship of Maternal Age to Birthweight: A Population-Based Test of the Weathering Hypothesis. Soc. Sci. Med. 1996, 42, 589-597. [CrossRef]

101. Abegunde, D.O.; Stanciole, A.E. The Economic Impact of Chronic Diseases: How Do Households Respond to Shocks? Evidence from Russia. Soc. Sci. Med. 2008, 66, 2296-2307. [CrossRef] [PubMed]

102. Champaloux, S.W.; Young, D.R. Childhood Chronic Health Conditions and Educational Attainment: A Social Ecological Approach. J. Adolesc. Health 2015, 56, 98-105. [CrossRef] [PubMed]

103. Jeon, Y.-H.; Essue, B.; Jan, S.; Wells, R.; Whitworth, J.A. Economic Hardship Associated with Managing Chronic Illness: A Qualitative Inquiry. BMC Health Serv. Res. 2009, 9, 182. [CrossRef]

104. Seeman, T.E.; Singer, B.; Wilkinson, C.W.; McEwen, B. Gender Differences in Age-Related Changes in HPA Axis Reactivity. Psychoneuroendocrinology 2001, 26, 225-240. [CrossRef]

105. Uchino, B.N.; Cacioppo, J.T.; Kiecolt-Glaser, J.K. The Relationship between Social Support and Physiological Processes: A Review with Emphasis on Underlying Mechanisms and Implications for Health. Psychol. Bull. 1996, 119, 488-531. [CrossRef]

106. Roy, M.P.; Steptoe, A.; Kirschbaum, C. Life Events and Social Support as Moderators of Individual Differences in Cardiovascular and Cortisol Reactivity. J. Personal. Soc. Psychol. 1998, 75, 1273-1281. [CrossRef]

107. Steptoe, A. Stress Responsivity and Socioeconomic Status. A Mechanism for Increased Cardiovascular Disease Risk? Eur. Heart J. 2002, 23, 1757-1763. [CrossRef]

108. Cohen, S.; Doyle, W.J.; Skoner, D.P. Psychological Stress, Cytokine Production, and Severity of Upper Respiratory Illness. Psychosom. Med. 1999, 61, 175-180. [CrossRef]

109. Daniel, M.; O’Dea, K.; Rowley, K.G.; McDermott, R.; Kelly, S. Social Environmental Stress in Indigenous Populations: Potential Biopsychosocial Mechanisms. Ann. N. Y. Acad. Sci. 1999, 896, 420-423. [CrossRef]

110. Schnorpfeil, P.; Noll, A.; Schulze, R.; Ehlert, U.; Frey, K.; Fischer, J.E. Allostatic Load and Work Conditions. Soc. Sci. Med. 2003, 57, 647-656. [CrossRef]

111. McEwen, B.S.; Seeman, T. Protective and Damaging Effects of Mediators of Stress: Elaborating and Testing the Concepts of Allostasis and Allostatic Load. Ann. N. Y. Acad. Sci. 1999, 896, 30-47. [CrossRef] [PubMed]

112. Zglinicki, T.; Martin-Ruiz, C. Telomeres as Biomarkers for Ageing and Age-Related Diseases. CMM 2005, 5, 197-203. [CrossRef] [PubMed]

113. Fuster, J.J.; Andrés, V. Telomere Biology and Cardiovascular Disease. Circ. Res. 2006, 99, 1167-1180. [CrossRef]

114. Okereke, O.I.; Prescott, J.; Wong, J.Y.Y.; Han, J.; Rexrode, K.M.; De Vivo, I. High Phobic Anxiety Is Related to Lower Leukocyte Telomere Length in Women. PLoS ONE 2012, 7, e40516. [CrossRef]

115. Simon, N.M.; Smoller, J.W.; McNamara, K.L.; Maser, R.S.; Zalta, A.K.; Pollack, M.H.; Nierenberg, A.A.; Fava, M.; Wong, K.-K. Telomere Shortening and Mood Disorders: Preliminary Support for a Chronic Stress Model of Accelerated Aging. Biol. Psychiatry 2006, 60, 432-435. [CrossRef]

116. Epel, E.S.; Blackburn, E.H.; Lin, J.; Dhabhar, F.S.; Adler, N.E.; Morrow, J.D.; Cawthon, R.M. Accelerated Telomere Shortening in Response to Life Stress. Proc. Natl. Acad. Sci. USA 2004, 101, 17312-17315. [CrossRef]

117. O’Donovan, A.; Epel, E.; Lin, J.; Wolkowitz, O.; Cohen, B.; Maguen, S.; Metzler, T.; Lenoci, M.; Blackburn, E.; Neylan, T.C. Childhood Trauma Associated with Short Leukocyte Telomere Length in Posttraumatic Stress Disorder. Biol. Psychiatry 2011, 70, 465-471. [CrossRef]

118. Tyrka, A.R.; Price, L.H.; Kao, H.-T.; Porton, B.; Marsella, S.A.; Carpenter, L.L. Childhood Maltreatment and Telomere Shortening: Preliminary Support for an Effect of Early Stress on Cellular Aging. Biol. Psychiatry 2010, 67, 531-534. [CrossRef] 
119. Verhoeven, J.E.; van Oppen, P.; Puterman, E.; Elzinga, B.; Penninx, B.W.J.H. The Association of Early and Recent Psychosocial Life Stress With Leukocyte Telomere Length. Psychosom. Med. 2015, 77, 882-891. [CrossRef]

120. Chae, D.H.; Nuru-Jeter, A.M.; Adler, N.E.; Brody, G.H.; Lin, J.; Blackburn, E.H.; Epel, E.S. Discrimination, Racial Bias, and Telomere Length in African-American Men. Am. J. Prev. Med. 2014, 46, 103-111. [CrossRef] [PubMed]

121. Lee, D.B.; Kim, E.S.; Neblett, E.W. The Link between Discrimination and Telomere Length in African American Adults. Health Psychol. 2017, 36, 458-467. [CrossRef] [PubMed]

122. Liu, S.Y.; Kawachi, I. Discrimination and Telomere Length Among Older Adults in the United States: Does the Association Vary by Race and Type of Discrimination? Public Health Rep. 2017, 132, 220-230. [CrossRef]

123. Pantesco, E.J.; Leibel, D.K.; Ashe, J.J.; Waldstein, S.R.; Katzel, L.I.; Liu, H.B.; Weng, N.-P.; Evans, M.K.; Zonderman, A.B.; Beatty Moody, D.L. Multiple Forms of Discrimination, Social Status, and Telomere Length: Interactions within Race. Psychoneuroendocrinology 2018, 98, 119-126. [CrossRef] [PubMed]

124. Benowitz, N.L. Pharmacology of Nicotine: Addiction and Therapeutics. Annu. Rev. Pharm. Toxicol. 1996, 36, 597-613. [CrossRef]

125. Benowitz, N.L. Pharmacologic Aspects of Cigarette Smoking and Nicotine Addiction. N. Engl. J. Med. 1988, 319, 1318-1330. [CrossRef]

126. Dallman, M.F.; Akana, S.F.; Laugero, K.D.; Gomez, F.; Manalo, S.; Bell, M.E.; Bhatnagar, S. A Spoonful of Sugar: Feedback Signals of Energy Stores and Corticosterone Regulate Responses to Chronic Stress. Physiol. Behav. 2003, 79, 3-12. [CrossRef]

127. Dallman, M.F.; Pecoraro, N.; Akana, S.F.; la Fleur, S.E.; Gomez, F.; Houshyar, H.; Bell, M.E.; Bhatnagar, S.; Laugero, K.D.; Manalo, S. Chronic Stress and Obesity: A New View of "Comfort Food". Proc. Natl. Acad. Sci. USA 2003, 100, 11696-11701. [CrossRef]

128. Folkman, S.; Chesney, M.A.; Pollack, L.; Phillips, C. Stress, Coping, and High-Risk Sexual Behavior. Health Psychol. 1992, 11, 218-222. [CrossRef]

129. Jackson, J.S. Health and Mental Health Disparities among Black Americans. In Modern Psychiatry: Challenges in Educating Health Professionals to Meet New Needs; Macy, J., Jr., Ed.; Foundation: New York, NY, USA, 2002; pp. 246-254.

130. Jackson, J.S.; Knight, K.M.; Rafferty, J.A. Race and Unhealthy Behaviors: Chronic Stress, the HPA Axis, and Physical and Mental Health Disparities over the Life Course. Am. J. Public Health 2010, 100, 933-939. [CrossRef]

131. Peele, S.; Brodsky, A. Exploring Psychological Benefits Associated with Moderate Alcohol Use: A Necessary Corrective to Assessments of Drinking Outcomes? Drug Alcohol. Depend. 2000, 60, 221-247. [CrossRef]

132. Robins, L.N. National Institute of Mental Health Diagnostic Interview Schedule: Its History, Characteristics, and Validity. Arch. Gen. Psychiatry 1981, 38, 381. [CrossRef] [PubMed]

133. Winkleby, M.A.; Cubbin, C. Racial/Ethnic Disparities in Health Behaviors: A Challenge to Current Assumptions. In Critical Perspectives on Racial and Ethnic Disparities in Health in Later Life; National Research Council: Washington, DC, USA, 2004; pp. 171-226.

134. Taylor, S.; Landry, C.A.; Paluszek, M.M.; Fergus, T.A.; McKay, D.; Asmundson, G.J.G. Development and Initial Validation of the COVID Stress Scales. J. Anxiety Disord. 2020, 72, 102232. [CrossRef] [PubMed]

135. Qiu, J.; Shen, B.; Zhao, M.; Wang, Z.; Xie, B.; Xu, Y. A Nationwide Survey of Psychological Distress among Chinese People in the COVID-19 Epidemic: Implications and Policy Recommendations. Gen. Psychiatry 2020, 33, e100213. [CrossRef] [PubMed]

136. Wang, C.; Pan, R.; Wan, X.; Tan, Y.; Xu, L.; Ho, C.S.; Ho, R.C. Immediate Psychological Responses and Associated Factors during the Initial Stage of the 2019 Coronavirus Disease (COVID-19) Epidemic among the General Population in China. IJERPH 2020, 17, 1729. [CrossRef]

137. Burström, B.; Tao, W. Social Determinants of Health and Inequalities in COVID-19. Eur. J. Public Health 2020, 30, 617-618. [CrossRef]

138. McNeely, C.L.; Schintler, L.A.; Stabile, B. Social Determinants and COVID-19 Disparities: Differential Pandemic Effects and Dynamics. World Med. Health Policy 2020, 12, 206-217. [CrossRef]

139. Singu, S.; Acharya, A.; Challagundla, K.; Byrareddy, S.N. Impact of Social Determinants of Health on the Emerging COVID-19 Pandemic in the United States. Front. Public Health 2020, 8, 406. [CrossRef]

140. Hall, G.L. Patient-Centered Clinical Care for African Americans A Concise, Evidence-Based Guide to Important Differences and Better Outcomes; Springer Nature: New York, NY, USA, 2019.

141. Jackson, C.S.; Gracia, J.N. Addressing Health and Health-Care Disparities: The Role of a Diverse Workforce and the Social Determinants of Health. Public Health Rep. 2014, 129 (Suppl. 2), 57-61. [CrossRef]

142. Mitchell, D.A.; Lassiter, S.L. Addressing Health Care Disparities and Increasing Workforce Diversity: The Next Step for the Dental, Medical, and Public Health Professions. Am. J. Public Health 2006, 96, 2093-2097. [CrossRef]

143. World Health Organization. Closing the Health Equity Gap: Policy Options and Opportunities for Action; World Health Organization: Geneva, Switzerland, 2013.

144. Njoku, A. Teaching Health Disparities Awareness in Undergraduate Public Health Courses. IJSOTL 2018, 12. [CrossRef] 